\title{
Productivity, Water Use, Quality and Economics of Pomegranate Fertigation in Semiarid Conditions of India
}

\author{
D. D. Pawar and S. K. Dingre* \\ Mahatma Phule Krishi Vidyapeeth, Rahuri, Maharashtra, India \\ *Corresponding author
}

\section{A B S T R A C T}

Field experiment was conducted in semi-arid western India for three consecutive years (2008-2010) to study the response of drip fertigation on yield, quality and economics of pomegranate. The experiment was laid out in a randomized block design with seven

\section{Keywords}

Drip irrigation, Fertigation,

Pomegranate yield,

Weekly splits,

Water soluble

fertilizers

Article Info

Accepted:

20 May 2020

Available Online:

10 June 2020 treatments replicated three times. The experiment comprised of 100,80 and $60 \%$ water soluble fertilizers applied through drip in 20 equal weekly splits and results were compared with four control treatments. The study indicated the beneficial effects of drip irrigation in terms of $23.5 \%$ increase in yield and $48.6 \%$ water saving whereas drip with fertigation resulted into 40 to $61 \%$ increase in pomegranate yield as compared to conventional method. The $100 \%$ recommended dose of fertilizer through drip in 20 weekly splits showed $61 \%$ increase in yield $\left(14.6 \mathrm{t} \mathrm{ha}^{-1}\right)$. However, it was on par with 80 $\%$ fertigation treatment $\left(13.7 \mathrm{t} \mathrm{ha}^{-1}\right)$. The pomegranate fruit yield obtained under $60 \%$ fertigation $\left(12.6 \mathrm{t} \mathrm{ha}^{-1}\right)$ produced $38.9 \%$ more yield as compared to farmer's practice $(9.05$ $\mathrm{t} \mathrm{ha}^{-1}$ ) indicating $40 \%$ fertilizer saving due to fertigation. Maximum water use efficiency $\left(79 \mathrm{~kg} \mathrm{ha}^{-1} \mathrm{~mm}^{-1}\right.$ ) was obtained in $100 \%$ fertigation. The fertigation resulted into B:C ratio in pomegranate in spite of very high market prices of water soluble fertilizers. The maximum net seasonal income (Rs. $475758 \mathrm{ha}^{-1}$ ), total net income (Rs. 922546), net extra income over conventional method (Rs. $217984 \mathrm{ha}^{-1}$ ) and maximum water productivity (Rs. $4607 \mathrm{~mm}^{-1}$ of water) were obtained in $100 \%$ fertigation however all the economical parameters were on par with $80 \%$ fertigation applied in 20 equal weekly splits.

\section{Introduction}

India is the largest producer of pomegranates (Punica granatum) in the world. Pomegranate is an important fruit crop and plays vital role in Indian agriculture economy. It is estimated that approximately 2 million tons of pomegranate are produced in the world. Out of this, 1 million ton are produced in India on
1.25 lakh ha area under cultivation of pomegranate. There has been a steady increase in area and production in the country and. by the year 2025, the area under pomegranate is projected to increase to 7.5 lakhs ha, from 1.25 lakhs ha at present. Consequently, production is expected to increase by 10 folds and export by 6.97 folds by the year 2025 (Anonymous, 2008). The 
total production of pomegranate in country is mainly concentrated in the western part (Maharashtra state). The area has acreage of pomegranate around 1 lakh ha with annual production of 8 lakh tons having average productivity of $8 \mathrm{t} \mathrm{ha}^{-1}$ (Anonymous, 2010). However, the productivity of state is lowest as compared to all other states. The major factors responsible for low pomegranate productivity in the region are poor irrigation management and imbalanced use of fertilizers. Thus, scientific control in the application of these two inputs certainly needed to improve pomegranate yield.

Most of the farmers in this region are now cultivating pomegranate on drip due to its potential to improve productivity as well as obtaining high remunerative returns. The increasing popularity of drip for pomegranate undoubtedly raised opportunities for improved fertilizer management but it leads to higher cost of cultivation including cost of fertilizers and their application. Recently, drip irrigation combined with fertigation has been found to benefit farmers because of the very high efficiency of fertilizer use (Solaimalai et al., 2005). Few research experiments have clearly demonstrated that the average yield increased to the tune of $40 \%$ by applying drip fertigation on pomegranate as compared to traditional irrigation and soil application (Firake and Kumbhar, 2002; Anonymous, 2010). Application of fertigation can enhance the fertilizer use efficiency, improves quality parameters and minimizes the water and nutrient losses to the extent of 25-30\% (Singh et al., 2006; James Ayars 2011). The application of water soluble fertilizer with appropriate apportioned splits through drip irrigation may lead to decrease in cost of cultivation and to improve the quality and quantity of fruit yields (Dhanumjaya Rao and Subramanyam, 2009). However, optimal schedule of fertilizer application through drip fertigation for pomegranate cultivation is not available. Thus, research studies on standardization of fertigation schedule for pomegranate and to assess its effect on growth, yield and quality in western India was undertaken.

\section{Materials and Methods}

The field experiment was conducted during three consecutive seasons from 2008 to 2010 at research farm of Mahatma Phule Krishi Vidyapeeth, Rahuri. Agroclimatically, the area falls under the scarcity zone of Maharashtra with annual average rainfall of $520 \mathrm{~mm}$ which is mostly erratic and uncertain in nature. The experimental plot was uniform and levelled with well drained, light medium soil, with $\mathrm{pH}$ as 7.40. The soil depth was 60 $\mathrm{cm}$ with hydraulic conductivity and organic carbon as $1.31 \mathrm{~cm} \mathrm{hr}^{-1}$ and $0.65 \%$, respectively. The soil texture was sandy clay loam with $11.67 \%$ coarse sand, $40.63 \%$ fine sand, $23.05 \%$ silt and $24.62 \%$ clay. The bulk density of soil was $1.43 \mathrm{~g} \mathrm{cc}^{-1}$ and electrical conductivity was $0.18 \mathrm{dSm}^{-1}$. The soil was high in available $\mathrm{N}\left(155.2 \mathrm{~kg} \mathrm{ha}^{-1}\right)$, and $\mathrm{P}$ $\left(15.81 \mathrm{~kg} \mathrm{ha}^{-1}\right)$ and very high in available $\mathrm{K}$ (300 $\mathrm{kg} \mathrm{ha}^{-1}$ ) content. The soil was having moisture contents at field capacity, permanent wilting point and available soil moisture as $29.90,14.31$ and $15.59 \%$ respectively. The experiment was conducted in newly established orchard planted at a spacing of 4.5 $\mathrm{x} 3.0 \mathrm{~m}$ during November, 2005. The harvesting was done in August 2008, 2009 and 2010 , respectively.

The field experiment was laid out in Randomized Block Design (RBD) with seven treatments replicated thrice with 8 plants under each plot. The treatments comprised of 100, 80 and $60 \%$ recommended dose in form of water soluble fertilizers (WSF) in 20 equal weekly splits $\left(\mathrm{T}_{1}, \mathrm{~T}_{2}, \mathrm{~T}_{3}\right)$, only $\mathrm{N}$ fertigation $\mathrm{P}$ \& $\mathrm{K}$ through soil $\left(\mathrm{T}_{4}\right)$, drip irrigation without fertigation $\left(T_{5}\right)$ conventional method of 
irrigation and fertilizer application $\left(\mathrm{T}_{6}\right)$ and farmer's practice $\left(T_{7}\right)$. The recommended dose of fertilizer considered for pomegranate was 625:250:250 N: $\mathrm{P}_{2} \mathrm{O}_{5}: \mathrm{K}_{2} \mathrm{O}$, g plant ${ }^{-1}$. The fertilizer dose for farmer's practice was 1382:320:602 gm plant $^{-1}$. In fertigation treatments water soluble fertilizer treatments, urea (46:0:0), urea phosphate (17:44:0) and muriate of potash $(0: 0: 60)$ were used for fertigation. In ' $\mathrm{N}$ ' fertigation $\left(\mathrm{T}_{4}\right)$, all the ' $\mathrm{N}$ ' was applied through urea in 20 equal weekly splits. In treatments $\mathrm{T}_{4}(\mathrm{P} \& \mathrm{~K}), \mathrm{T}_{5}$ and $\mathrm{T}_{6}$, the nutrients were applied through soil as per conventional practice.

The drip irrigation system was installed to meet out crop water requirement and for fertigation of water soluble fertilizers. The amount of water (litres day ${ }^{-1}$ ) to be applied through drip irrigation was calculated by the climatological approach method (Allen. et. al, 1994). The reference evapotranspiration was estimated using Evapotranspiration Monitoring Station (ICT International, Australia) installed at research farm. The lateral lines of $16 \mathrm{~mm}$ diameter LDPE pipes were laid along the crop rows and each lateral served each row of crop. The laterals were provided with two on-line drippers of $8 \mathrm{lph}$ discharge capacity plant $^{-1}$. The spacing between two adjacent laterals and emitters within plot was $4.50 \mathrm{~m}$ and $0.75 \mathrm{~m}$ from the trunk of either side, respectively. In case of surface irrigation, $80 \mathrm{~mm}$ depth of irrigation was applied at $75 \mathrm{~mm}$ of cumulative pan evaporation. The depth of water in surface method of irrigation was estimated using standard methodology. The growth, yield and quality parameters and its economics of pomegranate were studied.

\section{Results and Discussion}

\section{Yield contributing characters}

The pooled data for three years revealed that the fertigation significantly increased the yield and yield contributing characters of pomegranate as compared to drip irrigation without fertigation. The pooled yield contributing characters viz., number of fruits plant $^{-1}(93.57)$, size of fruit $(8.98 \mathrm{~cm})$, weight of fruit $(0.21 \mathrm{~kg})$ and 100 arils weight $(12.38$ g) were observed maximum in $100 \% \mathrm{WSF}$ fertilizers were applied in 20 splits over all other treatments. The drip irrigation with conventional fertilizers produced only 82.93 fruits. The surface method of irrigation produced only 68.14 fruits, which were lowest among all treatments. The weight of single fruit in $10 \%$ fertigation dose was at par with $80 \%$ and $60 \%$. The surface method of irrigation produced lowest weight of single fruit $(0.18 \mathrm{Kg})$. The values of yield contributing characters recorded in ' $N$ ' fertigation were also sizably high. This fact is supported by the works of Firake and Deolankar (2000) that the higher number of fruits plant ${ }^{-1}$, size of fruit and greater weight of fruit can be achieved with fertigation.

\section{Fruit yield}

The three years pooled data of pomegranate yield ranged between $9.05 \mathrm{t} \mathrm{ha}^{-1}$ to $14.58 \mathrm{tha}^{-1}$ (Table 1). Among various treatments, the significantly highest yield of $14.58 \mathrm{t} \mathrm{ha}^{-1}$ of pomegranate fruit was obtained in $100 \%$ recommended dose of fertilizer was applied in the form of urea phosphate, urea and murate of potash through drip. The yield under $100 \%$ fertigation dose was $60.8 \%$ more than farmer's practice. However, it was at par with $80 \%$ dose in 20 weekly splits.

The fruit yield obtained under drip irrigation without fertigation (N, P \& K through soil) was $11.19 \mathrm{t} \mathrm{ha}^{-1}$ which was found to be quite less than $60 \%$ fertigation $\left(12.60 \mathrm{t} \mathrm{ha}^{-1}\right)$. It indicated that fertigation using WSF can save fertilizer dose upto $40 \%$ with increase in yield. It is also revealed in $\mathrm{N}$ fertigation ( $\mathrm{P}$ and $\mathrm{K}$ through soil) that incurring slightly more cost, pomegranate yield can be 
increased sizably (12.70 $\left.\mathrm{t} \mathrm{ha}^{-1}\right)$ by applying urea through drip irrigation. The lowest yield of $9.05 \mathrm{t} \mathrm{ha}^{-1}$ was obtained farmers' practice. The reasons of low yield in surface irrigation might be that crop had to undergo water stress between two irrigations. The results are in conformity with Singh et al., (2006).

\section{Quality of juice}

The data indicated that the quality parameters viz., total soluble solids (TSS) and acidity were observed to be improved due to drip and fertigation significantly as compared to conventional method of irrigation (Table 2). The $\mathrm{pH}$, TSS were found maximum and minimum in acidity in fertigation@100\% which was at par with $80 \%$ dose. Application of water soluble fertilizers had a positive effect on TSS content. It is observed that as the fertilizer level increased, TSS content also increased. Increased moisture stress in surface irrigated treatments resulted into increased acidity of fruit.

\section{Organoleptic characteristics}

The organoleptic characters viz., colour, taste and texture of pomegranate (Table 2) were improved due to drip irrigation and fertigation. The $100 \%$ recommended dose as WSF through drip recorded superior taste, colour and texture, which was at par with 80 $\%$ dose. The surface method of irrigation (farmer's practice) recorded lowest colour rating (6.5). The surface method of irrigation also recorded minimum ratings for texture (6.70). The fertigation and drip irrigation treatments recorded the better taste rating as compared to conventional methods. The reasons for low quality of fruits in surface irrigation might be the high application of irrigation water leached down the nutrients below the root zone of crop. Similar trend of result are also reported by Firake and Kumbhar (2002).

\section{Water use}

The drip method of irrigation resulted into lowest water requirement $(194.2 \mathrm{~mm})$ as compared to surface method of irrigation $(376.97 \mathrm{~mm})$ and thus resulted into $48.73 \%$ water saving (Table 3). Thus, $100 \%$ recommended dose of fertilizer applied through drip resulted into $60.8 \%$ increase in yield with $48.73 \%$ water saving, where as only drip (without any fertigation) resulted into $23.48 \%$ increase in pomegranate yield with similar water saving. The treatment $\mathrm{T}_{3}$ (60\% WSF in 20 splits) resulted into $38.81 \%$ increase in yield with $40 \%$ saving in fertilizer and $48.73 \%$ saving in water. The drip irrigation and fertigation treatments resulted into higher values of water use efficiency (68.92 to $78.99 \mathrm{~kg} \mathrm{ha}^{-1} \mathrm{~mm}^{-1}$ ) as compared to farmer's practice of irrigation $(25.46 \mathrm{~kg}$ ha $\left.{ }^{1} \mathrm{~mm}^{-1}\right)$. The water use efficiency was increased to the tune of more than 3 times than conventional method. This is in confirmation with the findings of James Ayars (2011) that drip can increase the field water use efficiency.

\section{Cost economics}

The total cost of cultivation was computed by adding the seasonal fixed cost of drip irrigation with operational cost (Table 4). The seasonal fixed cost of drip system for pomegranate was estimated as Rs. 15658 considering 12 months crop period. It is revealed that more cost of cultivation was estimated in 100\% fertigation treatments (Rs. $146815 \mathrm{ha}^{-1}$ ) because of high market cost of water soluble fertilizers.

The drip method (without fertigation) and drip method with $\mathrm{N}$ through drip recorded the cost of cultivation as Rs. $125294 \mathrm{ha}^{-1}$. The lowest cost of cultivation was obtained for conventional method (Rs. 119287 ha $^{-1}$ ). 


\section{Net seasonal income and B: $\mathrm{C}$ ratio}

The maximum net seasonal income of Rs 4, $75,758 \mathrm{ha}^{-1}$ was recorded in $100 \%$ WSF in 20 weekly splits $\left(\mathrm{T}_{1}\right)$ which was on par with $80 \%$ WSF in 20 splits $\left(\mathrm{T}_{2}\right)$. Though, ' $\mathrm{N}$ ' fertigation resulted into 1.88 tonnes less yield of pomegranate, it resulted into slightly lower net income (Rs. $413120 \mathrm{ha}^{-1}$ ) than $100 \%$ fertigation due to low cost of cultivation. However, $\mathrm{N}$ fertigation recorded maximum $\mathrm{B}$ : $\mathrm{C}$ ratio (3.84) which was at par with $100 \%$ (3.83) and $80 \%$ fertigation dose (3.73).

The farmer's practice recorded lowest net seasonal income than any other treatments (Rs. $257774 \mathrm{ha}^{-1}$ ). The minimum B: C ratio of 2.89 was observed in farmer's practice. Singh et. al. (2006) also reported higher seasonal income accrued under fertigation in spite of high cost of water soluble fertilizers.

\section{Total net income}

The drip irrigation for pomegranate resulted into $48.63 \%$ water saving (average of three years) over conventional method of irrigation. Thus, it can bring 0.94 ha of additional area under irrigation (Table 4). The total net income calculated taking into consideration the additional area that can be brought under irrigation due to water saving in drip was found to the extent of Rs 9, 22, $545 \mathrm{ha}^{-1}$ in $100 \%$ fertigation, which was maximum followed by $80 \%$ fertigation with total net income as Rs. 8, 54, $087 \mathrm{ha}^{-1}$.

\section{Net extra income over farmer's practice}

The drip irrigation without fertigation resulted into Rs. 85462 ha $^{-1}$ (average over three years) net extra income $\mathrm{ha}^{-1}$ over farmer's practices. The drip irrigation with $100 \%$ fertigation produced Rs. 2, 17,984 ha ${ }^{-1}$ net extra income over control.

Table.1 Pooled yield and yield contributing characters of pomegranate fruit under different treatments of water soluble fertilizers (2007-2010)

\begin{tabular}{|l|l|c|c|c|c|c|}
\hline $\begin{array}{c}\text { Tr. } \\
\text { no. }\end{array}$ & \multicolumn{1}{|c|}{ Treatments } & $\begin{array}{c}\text { No. } \\
\text { fruits } \\
\text { plant }^{-1}\end{array}$ & $\begin{array}{c}\text { Size of fruit } \\
(\mathbf{c m})\end{array}$ & $\begin{array}{c}\text { Weight of } \\
\text { fruit }(\mathbf{K g})\end{array}$ & $\begin{array}{c}\mathbf{1 0 0} \text { arils } \\
\text { weight }(\mathbf{g})\end{array}$ & $\begin{array}{c}\text { Yield } \\
\mathbf{( t ~ h a}^{-\mathbf{1}} \mathbf{)}\end{array}$ \\
\hline $\mathbf{T}_{\mathbf{1}}$ & 100\% WSF & 93.57 & 8.98 & 0.21 & 12.38 & $\mathbf{1 4 . 5 8}$ \\
\hline $\mathbf{T}_{\mathbf{2}}$ & $80 \%$ WSF & 90.72 & 8.64 & 0.20 & 11.90 & $\mathbf{1 3 . 6 3}$ \\
\hline $\mathbf{T}_{\mathbf{3}}$ & 60\% WSF & 86.54 & 7.89 & 0.20 & 11.61 & $\mathbf{1 2 . 6 0}$ \\
\hline $\mathbf{T}_{\mathbf{4}}$ & 100\% CF (NTD) & 88.52 & 7.81 & 0.19 & 11.25 & $\mathbf{1 2 . 7 0}$ \\
\hline $\mathbf{T}_{\mathbf{5}}$ & 100\% CF +DI & 82.93 & 7.68 & 0.18 & 10.32 & $\mathbf{1 1 . 1 9}$ \\
\hline $\mathbf{T}_{\mathbf{6}}$ & 100\% CF +SI & 71.92 & 7.56 & 0.19 & 10.32 & $\mathbf{9 . 8 0}$ \\
\hline $\mathbf{T}_{\mathbf{7}}$ & Farmer's practice & 68.14 & 7.19 & 0.18 & 9.86 & $\mathbf{9 . 0 5}$ \\
\hline & SE $\mathbf{\pm}$ & 0.69 & 0.05 & 0.003 & 0.22 & $\mathbf{0 . 3 4}$ \\
\hline & CD at 5\% & $\mathbf{2 . 0 1}$ & $\mathbf{0 . 1 5}$ & $\mathbf{0 . 0 1 0}$ & $\mathbf{0 . 6 6}$ & $\mathbf{0 . 9 9}$ \\
\hline
\end{tabular}


Table.2 Quality and organoleptic parameters of pomegranate (Cv. Bhagwa) as influenced by different treatments (Pooled data of three years)

\begin{tabular}{|c|l|c|c|c|c|c|c|}
\hline Tr. no. & \multicolumn{1}{|c|}{ Treatments } & TSS & pH & Acidity & Colour & Taste & Texture \\
\hline $\mathbf{T}_{\mathbf{1}}$ & 100\% WSF & 19.26 & 2.99 & 0.31 & 8.09 & 8.05 & $\mathbf{7 . 2 3}$ \\
\hline $\mathbf{T}_{\mathbf{2}}$ & 80\% WSF & 19.08 & 2.96 & 0.31 & 7.88 & 7.57 & $\mathbf{7 . 0 9}$ \\
\hline $\mathbf{T}_{\mathbf{3}}$ & 60\% WSF & 18.94 & 3.06 & 0.31 & 7.62 & 7.48 & $\mathbf{6 . 9 8}$ \\
\hline $\mathbf{T}_{\mathbf{4}}$ & $100 \%$ CF (NTD) & 18.56 & 3.01 & 0.31 & 7.51 & 7.47 & $\mathbf{6 . 8 5}$ \\
\hline $\mathbf{T}_{\mathbf{5}}$ & $100 \%$ CF +DI & 18.35 & 2.97 & 0.32 & 7.08 & 7.24 & $\mathbf{6 . 7 1}$ \\
\hline $\mathbf{T}_{\mathbf{6}}$ & $100 \%$ CF +SI & 18.37 & 2.94 & 0.33 & 6.64 & 7.08 & $\mathbf{6 . 5 4}$ \\
\hline $\mathbf{T}_{\mathbf{7}}$ & Farmer's practice & 17.55 & 2.95 & 0.34 & 6.50 & 6.70 & $\mathbf{6 . 3 5}$ \\
\hline & SE \pm & 0.07 & 0.02 & 0.002 & 0.08 & 0.04 & $\mathbf{0 . 0 6}$ \\
\hline & CD at 5\% & $\mathbf{0 . 2 1}$ & $\mathbf{0 . 0 6}$ & $\mathbf{0 . 0 0 7}$ & $\mathbf{0 . 2 5}$ & $\mathbf{0 . 1 1}$ & $\mathbf{0 . 1 8}$ \\
\hline
\end{tabular}

Table.3 Water use of pomegranate (average of three years 2007-2010) under different treatments

\begin{tabular}{|c|c|c|c|c|c|c|}
\hline Treatments & $\begin{array}{l}\text { Water } \\
\text { applied } \\
(\mathbf{m m})\end{array}$ & $\begin{array}{c}\text { Effective } \\
\text { rainfall } \\
(\mathbf{m m})\end{array}$ & $\begin{array}{c}\text { Total water } \\
\text { use }(\mathbf{m m})\end{array}$ & $\begin{array}{c}\text { FWUE (Kg } \\
\left.\mathrm{ha}^{-1} \mathrm{~mm}^{-1}\right)\end{array}$ & $\begin{array}{c}\text { Water } \\
\text { saving over } \\
\text { farmer's } \\
\text { practice }(\%)\end{array}$ & $\begin{array}{l}\text { Increase in } \\
\text { yield over } \\
\text { farmer's } \\
\text { practice }(\%)\end{array}$ \\
\hline $100 \%$ WSF & 120.25 & 73.95 & 194.20 & 78.99 & 48.63 & 60.81 \\
\hline $80 \%$ WSF & 120.25 & 73.95 & 194.20 & 73.73 & 48.63 & 50.24 \\
\hline $60 \% \mathrm{WSF}$ & 120.25 & 73.95 & 194.20 & 68.13 & 48.63 & 38.81 \\
\hline $100 \%$ CF (NTD) & 120.25 & 73.95 & 194.20 & 68.92 & 48.63 & 40.03 \\
\hline $100 \% \mathrm{CF}+\mathrm{DI}$ & 120.25 & 73.95 & 194.20 & 61.37 & 48.63 & 23.48 \\
\hline $100 \% \mathrm{CF}+\mathrm{SI}$ & 213.95 & 146.43 & 360.38 & 28.63 & 4.43 & 8.08 \\
\hline Farmer's practice & 230.54 & 146.43 & 376.97 & 25.46 & 0.00 & 0.00 \\
\hline
\end{tabular}

Table.4 Economic analysis of pomegranate $\left(\mathrm{Rs} \mathrm{ha}^{-1}\right)$ as influenced by different treatments (pooled data of three years)

\begin{tabular}{|c|c|c|c|c|c|c|c|}
\hline Treatment & $\begin{array}{c}\text { Seasonal } \\
\text { Cost }\end{array}$ & $\begin{array}{c}\text { Net } \\
\text { seasonal } \\
\text { income }\end{array}$ & $\begin{array}{c}\text { Total } \\
\text { net } \\
\text { income }\end{array}$ & $\begin{array}{l}\mathrm{B}: \mathrm{C} \\
\text { ratio }\end{array}$ & $\begin{array}{c}\text { Net extra } \\
\text { income over } \\
\text { farmer's } \\
\text { practice }\end{array}$ & $\begin{array}{l}\text { Payback } \\
\text { period of } \\
\text { drip } \\
\text { (months) }\end{array}$ & $\begin{array}{c}\text { Net profit } \\
\text { Rs. } \text { mm }^{-1} \\
\text { of water } \\
\text { use }\end{array}$ \\
\hline $100 \%$ WSF & 162473 & 475758 & 922546 & 3.83 & 217984 & 0.28 & 4607 \\
\hline $80 \%$ WSF & 155737 & 440495 & 854087 & 3.73 & 182721 & 0.33 & 4262 \\
\hline $60 \%$ WSF & 149000 & 401293 & 778045 & 3.60 & 143519 & 0.42 & 3884 \\
\hline $100 \%$ CF (NTD) & 140952 & 413120 & 801209 & 3.84 & 155346 & 0.39 & 4023 \\
\hline $100 \% \mathrm{CF}+\mathrm{DI}$ & 140952 & 343236 & 666012 & 3.37 & 85462 & 0.70 & 3380 \\
\hline $100 \% \mathrm{CF}+\mathrm{SI}$ & 123626 & 288703 & 296635 & 3.05 & 30929 & -- & 802 \\
\hline Farmer's practice & 120767 & 257774 & 257774 & 2.89 & 0 & -- & 674 \\
\hline $\mathrm{SE} \pm$ & -- & 14760 & 14760 & 0.1 & 10708 & -- & 83.3 \\
\hline CD at $5 \%$ & -- & 39995 & 39995 & 0.2 & 32996 & -- & 243.2 \\
\hline
\end{tabular}




\section{Water productivity and payback period}

The net income obtained per unit of water was improved considerably to Rs. $4607 \mathrm{~mm}^{-1}$ in drip method of irrigation as compared to Rs. 802 in surface method of irrigation. This was followed by net profit of Rs. $4262 \mathrm{~mm}^{-1}$ obtained when $80 \%$ WSF were applied through drip. The drip with only $\mathrm{N}$ fertigation resulted into Rs. $4023 \mathrm{~mm}^{-1}$ of water whereas farmer's practice resulted into Rs. $674 \mathrm{~mm}^{-1}$ water productivity. Thus, drip coupled with fertigation showed its usefulness in using water six times more productively than conventional method of irrigation and fertilization.

Drip irrigation without fertigation come with Rs. $85462 \mathrm{ha}^{-1}$ additional net income over surface method, thus payback period of drip system is 0.70 years which reflected that cost of drip can be recovered within one season (Table 4). This emphasized the utility of drip irrigation for pomegranate irrespective of using water soluble fertilizers. The lower payback period was found when drip coupled with fertigation in treatments $(0.28-0.42$ year).

Water soluble fertilizers resulted into higher growth, yield and good quality of pomegranate fruit. fertigation @ $100 \%$ in 20 splits resulted into $60.81 \%$ more yield with $48.63 \%$ water saving where as only drip (without any fertigation) resulted into $23.5 \%$ increase in yield with similar water saving. The $60 \%$ fertigation resulted into $38.9 \%$ increase in yield as that of $100 \%$ recommended fertilizer $(\mathrm{N}, \mathrm{P} \& \mathrm{~K}$ through soil), indicating $40 \%$ saving in fertilizers due to use of water soluble fertilizer. The application of $100 \%$ WSF through drip also resulted into higher economical parameters but at par with $80 \%$ WSF through drip. The drip fertigation at $80 \%$ of recommended dose of water soluble fertilizers in 20 weekly splits through drip irrigation is found useful to pomegranate growers for increasing the yields, saving the fertilizers and water.

\section{References}

Allen R. G., Pareira L.S., Dirk R., and Smith M. 1994. Crop-EvaoptranspirationGuidelines for computing crop water requirements FAO Irrigation \& Drainage paper 56.

Anonymous 2010, Agricultural Production and Export Development Authority (APEDA) Database, Chapter 4:36-48.

Anonymous, 2008 Annual report of National Research Centre on Pomegranate.

Dhanumjaya Rao K. and Subramanyam K., 2009 Effect of nitrogen fertigation on growth and yield of pomegranate var. mridula under low rainfall zone. Agric. Sci. Digest, 29 (2): 1-3.

Firake, N. N. and Deolankar, K. P. 2000. Response of pomegranate to soluble fertilizers through drip. Journal of Maharashtra Agricultural Universities. 25(2): 196-197.

Firake, N.N. and Kumbhar, D.B. 2002 Effect of different levels of $\mathrm{N}, \mathrm{P}$ and $\mathrm{K}$ fertigation on yield and quality of Pomegranate. Journal of Maharashtra Agricultural Universities. 27(2): 146148.

James Ayars 2011 Improving pomegranate fertigation and nitrogen use efficiency with drip irrigation systems, Proceedings of $19^{\text {th }}$ Annual Fertilizer Research and Education Program Conference held at California Department of Food and Agriculture, Tulare, California, pp 29-33.

Meti C. B., Aladakatti Y. R., Khot A. B., Patil P. L., Mudkavi D. H., Radder B. M. and Patil S. G. 2008 Studies on optimum wetted area and pan fraction for higher yield and water use efficiency of pomegranate in vertisols of malaprabha 
command area. Karnataka J. Agric. Sci., 21(3): 469-470.

Patel N.M, Patel M.M. 1998. Water requirement of pomegranate (Punica granatum L.) cv. Ganesh for better yield under resource limited situations. National seminar on new horizons in production and post-harvest management of tropical and subtropical fruits, Delhi, Dec. 8-9.

Singh Prabhakar, Singh A.K., and Sahu Kamlesh 2006 Irrigation and fertigation of pomegranate cv. Ganesh in Chhattisgarh, Indian J. Hort. 63(2): 148-151.

Solaimalai A., Baskar M., Sadasakthi A. and Subburamu K. 2005 Fertigation in High Value Crops - A Review. Agric. Rev., 26(1): 1 - 13 .

Sulochanamma BN, Reddy TY, Reddy GS (2005). Effect of basin and drip irrigation on growth, yield and water use efficiency in pomegranate $\mathrm{cv}$. Ganesh. Acta Hort. 696: 277-279.

\section{How to cite this article:}

Pawar, D. D. and Dingre, S. K. 2020. Productivity, Water Use, Quality and Economics of Pomegranate Fertigation in Semiarid Conditions of India. Int.J.Curr.Microbiol.App.Sci. 9(06): 2503-2510. doi: https://doi.org/10.20546/ijcmas.2020.906.304 